\title{
Combined Prostaglandin and Nitric Oxide Inhibition Produces Anatomic Remodeling and Closure of the Ductus Arteriosus in the Premature Newborn Baboon
}

\author{
STEVEN R. SEIDNER, YAO QI CHEN, PATRICIA R. OPRYSKO, FRANCOISE MAURAY, \\ MARY M. TSE, EMIL LIN, CAMERON KOCH, AND RONALD I. CLYMAN \\ Cardiovascular Research Institute [Y.Q.C., F.M., R.I.C] and Departments of Pediatrics [Y.Q.C., F.M., \\ R.I.C] and Pharmacy [M.M.T., E.L.], University of California San Francisco; San Francisco, CA \\ 94143-0544, U.S.A.; Department of Pediatrics, University of Texas Health Sciences Center; San Antonio, \\ TX 78284, U.S.A. [S.R.S]; Department of Radiation Oncology, University of Pennsylvania; Philadelphia,
} PA 19104, U.S.A. [P.R.O., C.K.]

\begin{abstract}
After birth, the full-term ductus arteriosus actively constricts and undergoes extensive histologic changes that prevent subsequent reopening. These changes are thought to occur only if a region of intense hypoxia develops within the ductus wall after the initial active constriction. In preterm infants, indomethacininduced constriction of the ductus is often transient and is followed by reopening. Prostaglandins and nitric oxide both play a role in inhibiting ductus closure in vitro. We hypothesized that combined inhibition of both prostaglandin and nitric oxide production (with indomethacin and $N$-nitro-L-arginine (L-NA), respectively) may be required to produce the degree of functional closure that is needed to cause intense hypoxia. We used preterm ( 0.67 gestation) newborn baboons that were mechanically ventilated for $6 \mathrm{~d}$ : 6 received indomethacin alone, 7 received indomethacin plus L-NA, and 16 received no treatment (control). Just before necropsy, only $25 \%$ of control ductus and $33 \%$ of indomethacin-treated ductus were closed on Doppler examination; in contrast, $100 \%$ of the indomethacin-plus-L-NA-treated ductus were closed. Control and indomethacin-treated baboons developed negligible-to-mild ductus hypoxia (EF5 technique). Similarly, there was minimal evidence of ductus remodeling. In contrast, indomethacin-plus-L-NA-treated baboons developed intense hypoxia in regions where the ductus was most constricted. The hypoxic muscle strongly expressed vascular endothelial growth factor, and proliferating luminal endothelial cells
\end{abstract}

\section{ABSTRACT}

filled and occluded the lumen. In addition, cells in the most hypoxic regions were undergoing DNA fragmentation. In conclusion, preterm newborns are capable of remodeling their ductus, just like the full-term newborn, if they can reduce their luminal blood flow to a point that produces intense ductus wall hypoxia. Combined prostaglandin and nitric oxide inhibition may be necessary to produce permanent closure of the ductus and prevent reopening in preterm infants. (Pediatr Res 50: 365-373, 2001)

DA, ductus arteriosus

L-NA, $N$-nitro-L-arginine

MMA, $N$-monomethyl-L-arginine monoacetate salt

EF5, 2-(2-nitro-1H-imidazol-1-yl)-N-(2,2,3,3,3-

pentafluoropropyl) acetamide

NO, nitric oxide

Indo, indomethacin

eNOS, endothelial nitric oxide synthase

vWF, von Willebrand Factor

PECAM, platelet endothelial cell adhesion molecule (CD31)

PCNA, proliferating cell nuclear antigen

VEGF, vascular endothelial growth factor

TUNEL, terminal deoxynucleotidyl transferase nick-end labeling
In the full-term infant, closure of the DA occurs in two phases: 1) initial "functional" closure of the DA lumen by smooth muscle constriction, and 2) "anatomic" occlusion of the lumen resulting from endothelial proliferation, neointimal

Received January 30, 2001; accepted May 16, 2001.

Correspondence: Ronald I. Clyman, Box 0544, HSE 1492, University of California, San Francisco, 505 Parnassus Street, San Francisco, CA 94143-0544; e-mail: ric@itsa.ucsf.edu thickening, and loss of smooth muscle cells from the inner muscle media $(1,2)$. Hypoxia of the DA wall seems to be the required stimulus for irreversible, anatomic closure (3). Anatomic remodeling occurs only in the presence of moderate to intense hypoxia (3).

Supported, in part, by U.S. Public Health Service National Heart, Lung, Blood Institute grants HL46691 and HL56061, and a gift from the Perinatal Associates Research Foundation. The BPD Resource Center is funded by grant HL52636. 
Oxygen normally reaches the muscle media of the DA through either the vessel's lumen or its adventitial vasa vasorum (3). Arterial wall oxygenation is highest immediately adjacent to the vessel's lumen, diminishes to a nadir in the middle of the muscle media, and increases progressively again toward the vasa vasorum-rich adventitia (4). In the full-term DA, a marked increase in the thickness of the DA wall during postnatal constriction increases the diffusion path for oxygen and produces intense hypoxia in the middle of muscle media, even before luminal flow is completely abolished (3). In the premature DA, even when postnatal constriction reduces the size of the vessel's lumen to the same extent as at term, the increase in vessel wall thickness is only one third of that seen at term. This shortened diffusion path makes the immature DA less susceptible to developing hypoxia. As a result, profound hypoxia and anatomic remodeling frequently fail to develop (3). In the following study, we hypothesized that if we could make the preterm DA completely obliterate its lumen, it might develop the degree of hypoxia needed to initiate the remodeling process.

Muscular constriction of the DA depends on a balance between dilating and contracting forces. The DA in the preterm newborn develops less contractile tension than it does at term because of the inhibitory effects of endogenous vasodilators, like prostaglandins and NO (5-10). Inhibition of prostaglandin production with indomethacin is an effective means of constricting the premature patent DA (11). Indomethacin treatment leads to the elimination of Doppler-demonstrable luminal blood flow; however, the preterm DA still has a high rate of reopening (11). We hypothesized that, although NO plays a smaller role than prostaglandins in opposing DA constriction in vitro $(5,6)$, combined inhibition of both prostaglandin and $\mathrm{NO}$ production may be required to produce the necessary degree of constriction that would completely obliterate the DA lumen and produce DA wall hypoxia. In the following study, we used premature baboons to test the hypothesis that the preterm newborn is capable of remodeling its DA, just like the full-term newborn, if it can constrict its DA to a point that obliterates its lumen and produces DA wall hypoxia.

\section{METHODS}

We used preterm fetal and newborn baboons (Papio sp.) ( $125 \mathrm{~d}$ gestation; full term $=185 \mathrm{~d}$ ) to examine the effects of indomethacin and inhibitors of NO production on ductus closure. Animal care, surgery, and necropsy were performed at the Southwest Foundation for Biomedical Research (San Antonio, TX, U.S.A.). Animals were killed with an overdose of pentobarbital sodium. Preterm fetal baboons (125 d gestation, $n=$ 14) were delivered by cesarean section and killed before breathing. Preterm newborns $(n=32)$ were delivered by cesarean section at $125 \mathrm{~d}$ gestation and cared for in the primate intensive care nursery for the first $6 \mathrm{~d}$ after delivery (3). Ventilator and intensive care nursery management were performed as previously described (3). Preterm newborns were killed on d 6 (144 h after delivery). These procedures were approved by the Committee on Animal Research at the Southwest Foundation for Biomedical Research.
Experimental groups. Preterm newborns received one of four treatment protocols: 1) indomethacin alone (Indo, $n=6$ ); 2) indomethacin plus L-NA, a NO synthase inhibitor (Indo + $L-N A, n=7)$; 3) indomethacin plus MMA, a NO synthase inhibitor (Indo + MMA, $n=3$ ); or 4) no treatment (Control, $n=16$ ).

Indomethacin (Indocin, $0.1 \mathrm{mg} / \mathrm{kg} / \mathrm{dose}$ ) was given i.v. (over $20 \mathrm{~min}$ ) at 24, 48, 72, 84, 96, 108, 120, and $132 \mathrm{~h}$ after delivery to animals in groups Indo, Indo $+L-N A$, and Indo $+M M A$. This dosing schedule was chosen because higher doses $(0.2$ $\mathrm{mg} / \mathrm{kg}$ ) produced anuria (12). Indo $+L-N A$ animals received an infusion of L-NA (Sigma Chemical, St. Louis, MO, U.S.A.) $(6 \mathrm{mg} / \mathrm{kg} / \mathrm{h})$, starting at $50 \mathrm{~h}$ after delivery; the infusion was continuously administered until necropsy. L-NA $(185 \mathrm{mg})$ was dissolved in $1 \mathrm{~mL} \mathrm{HCl}(1 \mathrm{~N})$, buffered with $\mathrm{NaOH}(1 \mathrm{~N})$, and brought to the appropriate volume with $\mathrm{D} 10 \mathrm{~W}$. Indo $+M M A$ animals received an infusion of MMA (Calbiochem, San Diego, CA, U.S.A.) $(20 \mathrm{mg} / \mathrm{kg} / \mathrm{h})$, starting at $50 \mathrm{~h}$ after delivery, that was continuously administered until necropsy. MMA was dissolved in $\mathrm{H}_{2} \mathrm{O}$ and brought to the appropriate volume in D10W. Previous studies in fetal sheep have shown that inhibition of NO synthesis alone produces minimal ductus constriction in vivo compared with the inhibition of prostaglandin synthesis $(8,13)$. This may be the result in part of the increase in prostaglandin production that occurs after inhibition of $\mathrm{NO}$ synthesis (R. Clyman, unpublished results; 14)). Therefore, we began the infusions of the NO synthase inhibitors $26 \mathrm{~h}$ after starting indomethacin so that the NO synthase inhibitors would only affect NO synthesis and not stimulate prostaglandin synthesis. The doses of L-NA and MMA that we chose have similar inhibitory effects on NO production (15). Infusion rates of L-NA and MMA were reduced by $25 \%$ if mean systemic blood pressure was consistently $>47 \mathrm{~mm} \mathrm{Hg}$; at necropsy the infusion rates were $5.6 \pm 1.1 \mathrm{mg} / \mathrm{kg} / \mathrm{h}$ for L-NA and $18.3 \pm$ $2.9 \mathrm{mg} / \mathrm{kg} / \mathrm{h}$ for MMA.

Serum nitrates. Using a NO analyzer (model 280, Sievers, Boulder, CO, U.S.A.), we found that MMA $(n=3)$ caused a marked reduction in NO release (measured by nitrate reaction products in the serum). We found that serum nitrates fell from preinfusion values of $104 \pm 18$ and $101 \pm 10 \mu \mathrm{M}$ (at 25 and $46 \mathrm{~h}$ after delivery, respectively) to $61 \pm 4$ and $45 \pm 12 \mu \mathrm{M}$ (at 47 and $71 \mathrm{~h}$, respectively) after starting the MMA infusion.

Indomethacin concentrations. Plasma indomethacin concentrations were measured as we have described previously (16). There were no significant differences in peak indomethacin concentrations, measured $1 \mathrm{~h}$ after the last dose of indomethacin, between animals in the Indo group $(381 \pm 165$ $\mathrm{ng} / \mathrm{mL}, n=6)$ and those in the Indo $+L-N A$ group $(561 \pm 223$ $\mathrm{ng} / \mathrm{mL}, n=6)$. In addition, there were no significant differences in peak indomethacin concentrations, after the final indomethacin dose, between those baboons with an open DA lumen $(421 \pm 174 \mathrm{ng} / \mathrm{mL}, n=6)$ and those with a closed DA lumen $(521 \pm 246 \mathrm{ng} / \mathrm{mL}, n=6)$ at necropsy.

Pulsed-Doppler studies. Pulsed-Doppler flow studies were performed daily, using an $8-\mathrm{mHz}$ transducer interfaced with a Biosound ND256 echocardiographic system to confirm the presence, direction, and timing of ductus flow (3). Dynamic compliance and expiratory airway resistance were measured 
with a VT1000 Vital Station Neonatal Plethysmograph (Vitaltrends Technology, Wallingford, CT, U.S.A.).

Tissue preparation. Necropsies were performed immediately after the last Doppler examination. The DA was dissected in Dulbecco's PBS solution at $4^{\circ} \mathrm{C}$. The minimal luminal diameter was measured and the DA was embedded in Tissuetek (Bayer Corp., Elkhart, IN, U.S.A.) and frozen in liquid nitrogen. In some experiments, the DA was divided in two: one half was embedded in Tissuetek and frozen in liquid nitrogen, whereas the other half was fixed for $5 \mathrm{~h}$ in fresh $4 \%$ paraformaldehyde at $4{ }^{\circ} \mathrm{C}$ before paraffin embedding.

\section{Detection of hypoxia with EF5.}

To detect regions of hypoxia within the DA, we used the EF5 detection system that we have described previously (3, 17). EF5 binds to cysteine residues of cellular proteins after it has been acted upon by intracellular, hypoxia-dependent nitroreductases (18). When it has been studied in different cell lines, tissues, and species, both in vivo and in vitro, EF5 has been found to have a similar oxygen dependency for its rate of binding (18). There is a 50- to 100-fold dynamic range of EF5 binding when tissue $\mathrm{O}_{2}$ concentrations change from 10 to $<0.1 \%$ oxygen $(3,18)$.

We gave the premature baboons EF5 $\left(10^{-4} \mathrm{~mol} / \mathrm{kg}\right.$ (30 $\mathrm{mg} / \mathrm{kg}$ i.v. over $10 \mathrm{~min}) 36 \mathrm{~h}$ before necropsy. Blood samples were collected at $1,6,12,24$, and $36 \mathrm{~h}$ after the dose and analyzed for EF5 as previously described (3). The in vivo exposure of tissues to EF5 was calculated from the area under the curve of the EF5 serum concentrations and was similar among the groups (data not shown).

We have shown previously that EF5 binding in vivo can be assessed quantitatively using immunofluorescent techniques $(3,18)$. We used MAb (ELK 3-51), which is highly specific for EF5 tissue adducts, to detect the presence of bound EF5 in the tissue. Direct digital image acquisition was performed with a "Quantix" CCD camera (Photometrics, Tucson, AZ, U.S.A.) and the digitized images were analyzed with National Institutes of Health "Image" software and Adobe Photoshop (Adobe Systems, Mountain View, CA, U.S.A.). The microscope was calibrated for constant light output as previously described (3). For digital analysis, the exposure time was set by the camera's automatic exposure system. We assigned a "relative intensity" to a microscopic field by considering the range of pixel intensities and the total camera exposure time. These procedures allowed us to adjust the camera exposure times to provide visually acceptable images while preserving the absolute intensity information. The absolute intensity values were corrected for the in vivo EF5 drug exposure and were expressed as a percent of the calculated maximal expected binding (18). In these experiments, two types of control tissues were used: 1) tissue from animals that were not given EF5 and 2) tissue from EF5-treated animals that were stained with ELK 3-51 antibody plus $0.5 \mathrm{mM}$ EF5 to tie up specific antibody binding sites. There was no staining of either control tissue (data not shown).

In some experiments, the nucleophilic dye, Hoechst No. 33342 (Sigma Chemical) bisbenzimide, $(20 \mathrm{mg} / \mathrm{kg}$ ) was administered to the animals, i.v., 15 min before necropsy. Be- cause this fluorescent dye readily intercalates into cellular DNA in vivo, it can be used to demonstrate regions of the DA that were perfused and had access to the dye (as measured by Hoechst bisbenzimide uptake) just before necropsy.

Immunohistochemistry. Protocols for the immunohistochemistry of eNOS, vWF, PECAM (CD-31), PCNA, VEGF, and EF5 were similar to those reported previously $(3,5)$. To detect endothelial cells, we incubated frozen sections with either mouse monoclonal anti-eNOS (Clone 3, Transduction Laboratories, Lexington, KY, U.S.A.), anti-PECAM (R \& D Systems, Minneapolis, MN, U.S.A.), or rabbit anti-vWF (DAKO, Carpinteria, CA, U.S.A.) antibodies. To detect EF5 binding, we incubated frozen sections with mouse MAb, ELK 3-51, conjugated with the fluorescent dye Cy3.

Paraffin-embedded sections were rehydrated and incubated with rabbit anti-VEGF antibody (Santa Cruz Biotechnology, Santa Cruz, CA, U.S.A.). Scoring for VEGF was as follows: 0, no staining; $1+$, mild staining; and $2+$, moderate staining. All sections were stained in the same assay. Assays were reproduced on three separate occasions. Control sections were incubated with either rabbit IgG (Sigma Chemical) or anti-VEGF antibody that had been preabsorbed to excess amounts of control VEGF peptide. There was no staining of control tissues (data not shown).

PCNA is present in proliferating cells during $\mathrm{S}, \mathrm{G} 1$, and G2 phases of the cell cycle (19). We used a monoclonal antiPCNA antibody (Santa Cruz Biotechnology) to monitor endothelial cell proliferation $(19,20)$ as we have described previously (3). In each experiment, we used sections of baboon small intestine to demonstrate the specificity of PCNA staining because its sites of proliferation are known (20). The total number of PCNA-positive cells per 100 cells lining the ductus lumen were determined by counting 100 cells from each of four separate predetermined quadrants of the vessel's lumen.

Histologic measurements were made at the level of minimal luminal area, which was determined from serial sections made through the tissue. Tissue dimensions were determined by averaging measurements made from eight predetermined regions of the section, using an overlay template and National Institutes of Health Image software. All measurements were made from sections stained for eNOS because antibodies made against eNOS, PECAM, and vWF showed the same pattern of endothelial cell distribution. The neointimal zone was defined as the region between the luminal endothelial cells and the internal elastic lamina (identified by phase contrast microscopy). The depth of vasa vasorum ingrowth, into the muscle media, was based on the presence of vasa vasorum within predetermined concentric regions that partitioned the DA wall between the intima and the adventitia (5).

Cell death. We used the TUNEL technique to detect cells in the early stages of DNA fragmentation and cell death as we have described previously (3). This technique identifies cells undergoing necrosis (21) as well as apoptosis (22). DNA breaks were detected with the fluorescein-conjugated dUTP Apotag detection system (Oncor, Gaithersburg, MD, U.S.A.). There was no nonspecific binding of reagents to nuclei when TdT was omitted from the assay (data not shown). In contrast, when sections were pretreated with DNAse I, all of the nuclei 
stained positively (data not shown). The number of TUNELpositive nuclei per 100 nuclei was scored in the region of EF5 staining. Regions of the section that had negligible EF5 binding had no TUNEL positive nuclei (see below).

Statistics. Results are presented as means \pm SD unless otherwise indicated. Intergroup differences were evaluated with either a $\chi^{2}$ analysis or unpaired $t$ test. When more than one comparison was made, Bonferroni's correction was used.

\section{RESULTS}

Among the 16 control newborns, only 4 (25\%) closed their DA on Doppler examination by d 6. Sixty-six percent of the newborns treated with indomethacin alone closed their DA on Doppler examination at some point during the experiment (Fig. 1); however, only 33\% were still closed on the Doppler exam on $\mathrm{d} 6$. In contrast, $90 \%$ of newborns treated with indomethacin and a NOS inhibitor (either L-NA or MMA) had a closed DA on Doppler examination on d 6 (Fig. 1).

Although no Doppler flow could be detected in $25 \%$ of the Control newborns, a small patent lumen $(>0 \mathrm{~mm}$ diameter) was still visible at the time of necropsy in all of the Control DA (Fig. 2A). There was no significant difference in the size of the DA lumen at necropsy between the Control and Indo newborns (Fig. $2 A$ ). In contrast, $80 \%$ of the newborns treated with both indomethacin and a NOS inhibitor (either L-NA or MMA) had a closed lumen at necropsy ( $p<0.05$ versus Control or Indo groups) (Fig. 2A).

We injected the hypoxia indicator, EF5, into the preterm newborns $36 \mathrm{~h}$ before necropsy. DA from the Control and Indo groups had only negligible-to-mild EF5 binding (Figs. 3 and $4 A$ ). In contrast, DA from newborns treated with Indo $+L-N A$ had intense EF5 binding, indicating profound hypoxia (Figs. 3 and 4, $C$ and $E$ ) (see Refs. 17 and 23 for correlation between EF5 binding and tissue oxygen concentration). Differences in the amount of EF5 binding depended on the degree of DA constriction (Fig. 3). The marked increase in EF5 binding in the Indo $+L-N A$ animals was observed only in the portion of the DA with extensive reduction in luminal area. Sections taken near the aortic end of the DA (that still contained a widely patent lumen) had negligible EF5 binding.

The site of maximum EF5 binding within the DA wall also was dependent on the amount of luminal perfusion (as measured by Hoechst bisbenzimide uptake) (Fig. 4). As long as there was any evidence of luminal perfusion (Fig. 4B), maximum EF5 binding occurred in the middle of the muscle media (Fig. 4C), halfway between the two sources of DA wall perfusion (lumen and vasa vasorum) (Fig. 4, $B$ and $C$ ). In contrast, if luminal perfusion was completely obliterated (Fig. $4 D)$, maximum EF5 binding occurred in the region furthest from the vasa vasorum - the central neointima inner media (Fig. 4, $D$ and $E$ ).

We used the TUNEL assay of DNA fragmentation to identify cells that were in the early stages of cell death. TUNELpositive cells were found exclusively in regions of Indo + $L-N A$-treated DA that had intense EF5 binding (Fig. 4, $E$ and $F$, and Fig. 5). Sections taken from the aortic end of the Indo
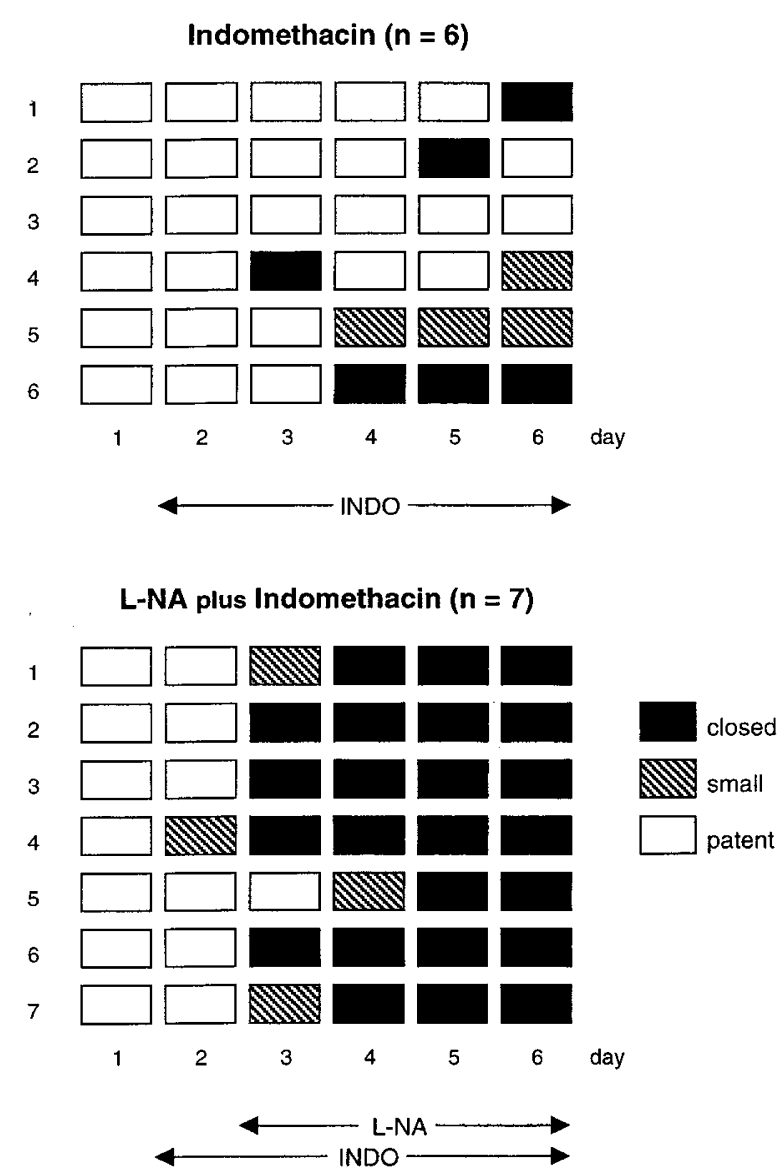

MMA plus Indomethacin $(n=3)$

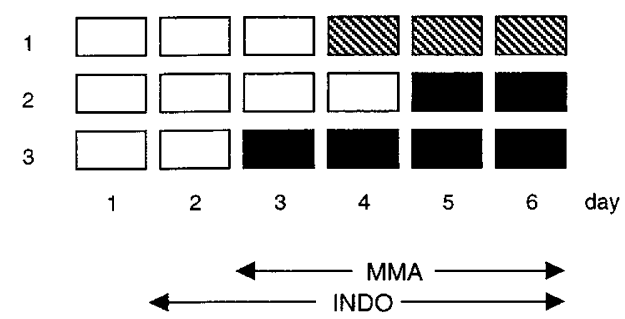

Figure 1. Luminal patency of the DA detected by echocardiogram/Doppler examination. Daily measurements of DA patency were performed as described in "Methods." Double arrowheads indicate the duration of treatment with either indomethacin, or the two NO synthase inhibitors (L-NA and MMA). A small lumen equals a short, high-velocity jet; a patent (bigger) lumen equals a more continuous, low-velocity jet.

+ L-NA DA, which had negligible EF5 binding, had no TUNEL-positive nuclei $(0 \pm 0)$.

During the first days after birth, endothelial cells that line the DA lumen in the full-term DA proliferate and become a significant component of the expanding neointima $(1,2)$. Therefore, we looked at VEGF expression during DA closure because VEGF is induced by hypoxia (24) and plays an important role in endothelial cell proliferation and migration (25). We were unable to detect VEGF by immunohistochemistry in the muscle media of the preterm fetal DA (Fig. 6A). In contrast, smooth muscle cells in the hypoxic zone of the preterm newborn DA did express detectable levels of VEGF 
A) Ductus lumen diameter - Necropsy

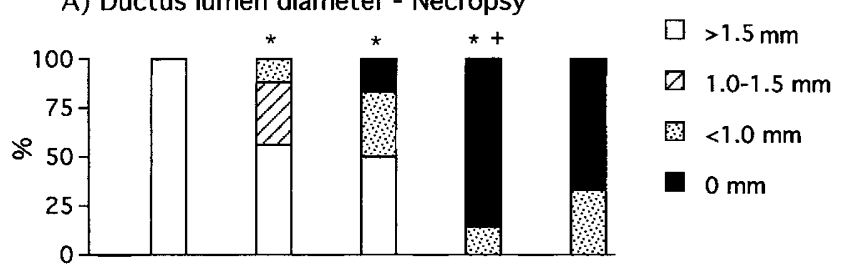

B) Neointimal Thickness

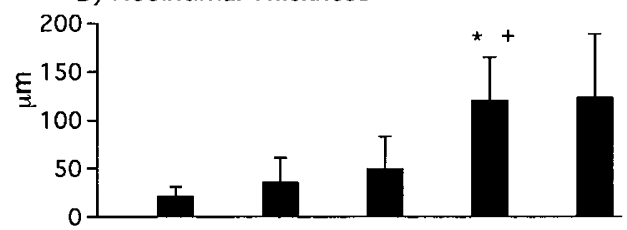

C) Luminal Endothelium

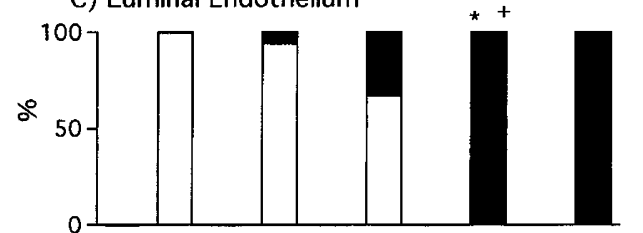

D) Vasa Vasorum Ingrowth

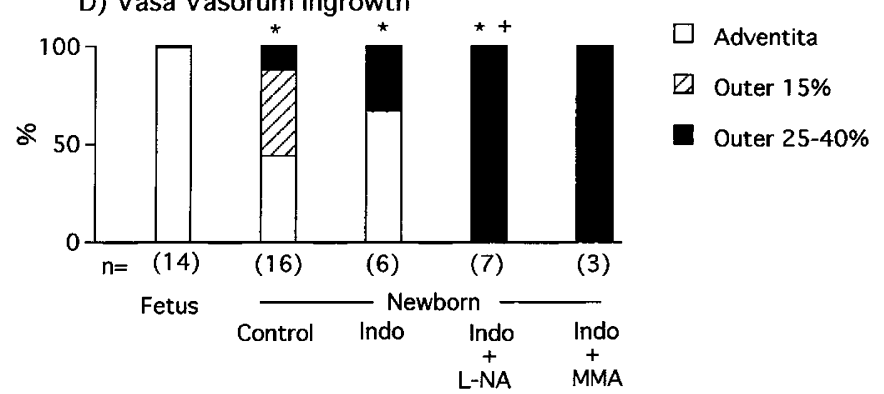

Figure 2. Relationship between DA treatment group and measurements of DA constriction, neointimal thickness, luminal endothelial accumulation, and vasa vasorum ingrowth. $(A)$ Narrowest measurement of luminal diameter at the time of necropsy. $(B)$ Neointimal thickness $(\mu \mathrm{m})$ : means ( $\pm \mathrm{SD})$. (C) Luminal endothelium. The eNOS-positive endothelial cells that lined the DA lumen formed either single or multiple (three) layers. $(D)$ Vasa vasorum ingrowth. Four separate, random sections from the middle of the DA were stained for eNOS and photographed. The muscle media was partitioned into concentric regions based on the percentage of muscle media thickness between the intima and adventitia. Vessel ingrowth was categorized based on the innermost region of the wall that contained at least one vasa vasorum $* p<0.05 v$ fetal DA; $+p$ $<0.05$ vs Indo-alone group.

(Fig. 6A). There was significantly greater VEGF expression in the smooth muscle cells of the Indo $+L-N A$ DA than in those from the Control or Indo-treated newborns $(p<0.05)$ (Fig. $6 A$ and Fig. 7, $A$ and $D$ ). Differences in the amount of VEGF expression depended on the degree of DA constriction [VEGF versus diameter of DA lumen, $p<0.01$, (Fig. 6B)].

We examined the rate of luminal endothelial cell proliferation by monitoring the number of PCNA-positive cells that lined the ductus lumen. There were very few PCNA-positive endothelial cells lining the DA lumen of the Control and Indo newborns $[1.5 \pm 1.7(n=7)$ and $0.5 \pm 0.9(n=4)$ PCNApositive cells per 100 cells, respectively]. In contrast, the DA of the Indo $+L-N A$ animals had an increased number of PCNA-positive endothelial cells $(17 \pm 5, n=5, p<0.05$ versus Control and Indo DA).

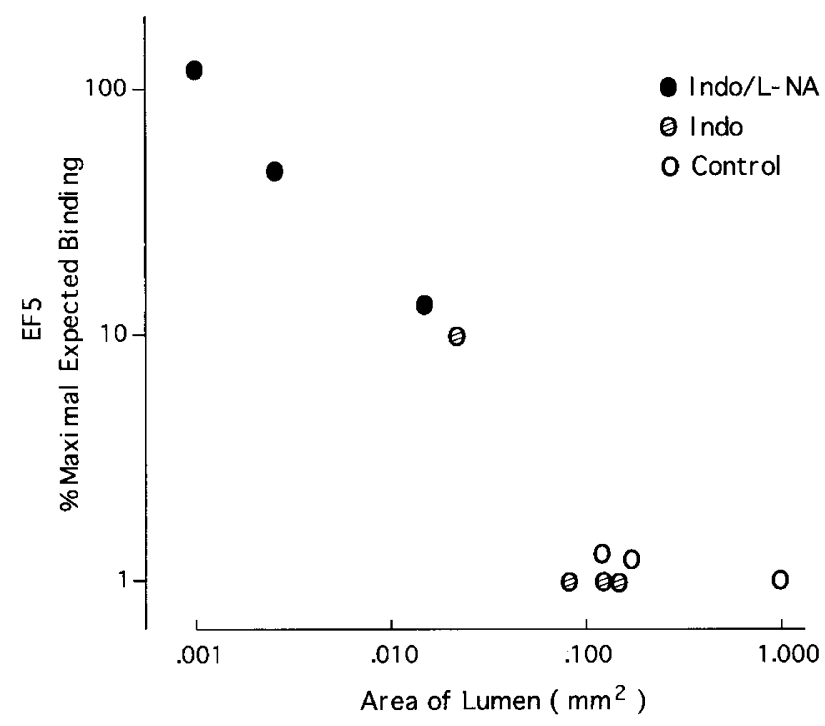

Figure 3. EF5 binding to 6-d-old premature newborn DA. Sections of DA, obtained from controls $(n=3)$ and indomethacin- $(n=4)$, and indomethacin plus L-NA-treated $(n=3)$ baboons, were taken from the most constricted region of the vessel. EF5 binding was expressed as a percent of maximal expected binding based on the in vivo EF5 drug exposure (see "Methods").
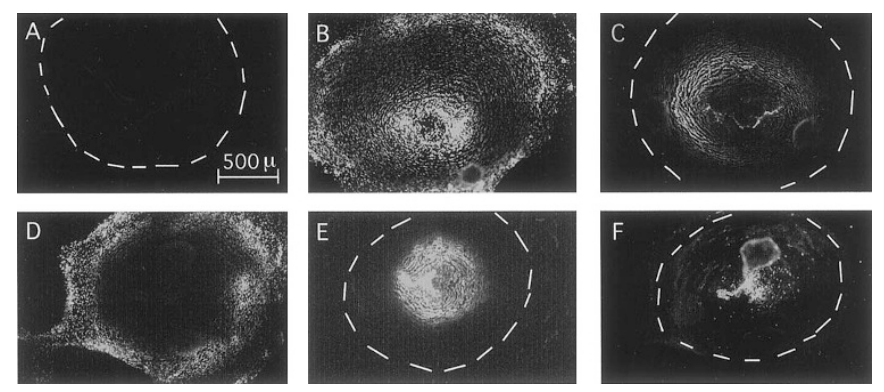

Figure 4. Hypoxia marker (EF5) $(A, C, E)$ and perfusion marker (bisbenzimide) $(B, D)$ binding, and DNA fragmentation (TUNEL staining) $(F)$ in the premature baboon DA. DA were removed from newborns treated with either Indomethacin alone $(A)$ or Indomethacin plus L-NA $(B-F)$ that had been given EF5 and bisbenzimide. Ten-micron sections from the middle of the DA were stained with ELK3-51 to detect EF5 (A, C, E). Horizontal bar represents 500 $\mu \mathrm{m}$. Each figure is photographed at the same magnification. Dashed white line indicates outer edge of DA muscle media (identified by phase contrast microscopy). (A) Indo-alone: DA had only a small lumen (diameter $<1.0 \mathrm{~mm}$ ) at necropsy and negligible EF5 binding. $(B, C)$ Adjacent sections from the same Indo $+L-N A$ DA that was closed at necropsy (diameter $=0 \mathrm{~mm}$.). Despite its appearance at necropsy, bisbenzimide-stained cells near the vasa vasorum as well as cells around the visibly closed lumen, indicating the presence of some luminal perfusion at the time of necropsy $(B)$. There was marked EF5 binding in the middle of the muscle media (between the closed lumen and vasa vasorum) $(C) .(D-F)$ Adjacent sections from the same Indo + L-NA DA that was closed at necropsy (diameter $=0 \mathrm{~mm}$ ). Only cells adjacent to the vasa vasorum were stained by bisbenzimide, indicating lack of luminal perfusion $(D)$; there was intense binding of EF5 in the central intimal-inner media region $(E)$; cells in the center of the EF5 binding region $(E)$ had TUNEL-positive nuclei (white dots) $(F)$

Among the Control and Indo newborns, only $6 \%$ and $33 \%$, respectively, had evidence of endothelial cell accumulation in the DA lumen (Fig. 2C); the rest were lined by a single layer of luminal endothelial cells (Fig. $7 E$ ). In contrast, all of the DA from the Indo $+L-N A$ newborns had neointimal mounds filled with endothelial cells (Fig. $2 C$ and Fig. $7 B$ ). The DA from the 


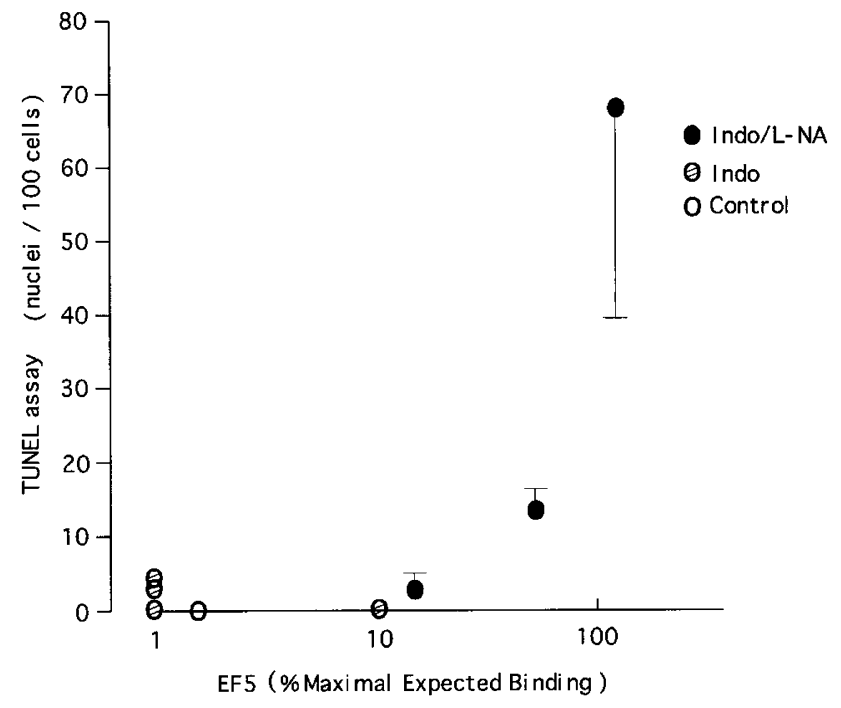

Figure 5. Profound hypoxia is associated with DNA fragmentation. The number of TUNEL-positive nuclei is expressed per 100 muscle media nuclei in the region of greatest EF5 binding. Values represent mean \pm SD.

A) VEGF expression

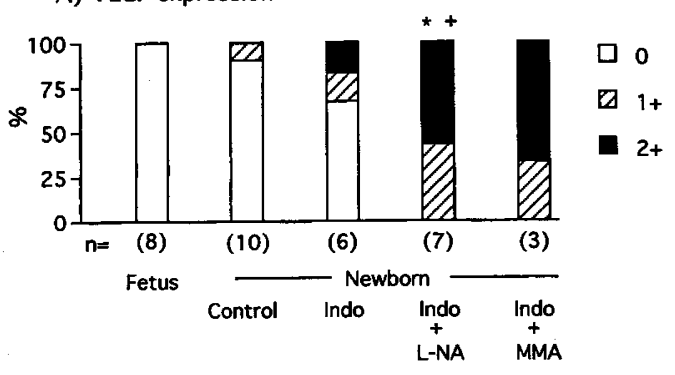

B) Newborn Ductus

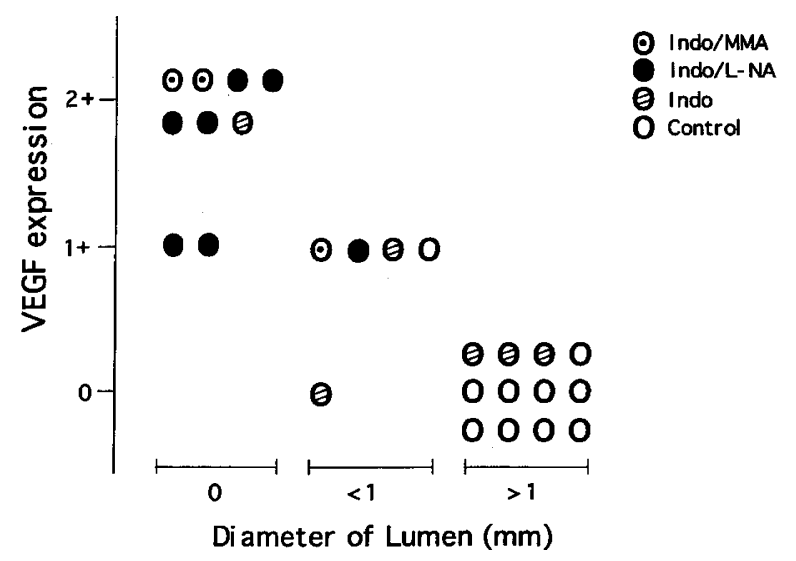

Figure 6. Relationship between $(A)$ DA treatment group and $(B)$ degree of DA constriction and VEGF expression. Units of VEGF $(0-2)$ refer to intensity of immunostaining. Diameter of lumen: narrowest measurement of luminal diameter at the time of necropsy. ${ }^{*} p<0.05 v s$ fetal DA; $+p<0.05 v s$ Indo-alone group.

Indo $+L-N A$ baboons also had a significantly thicker neointima than the DA from the Control or Indo baboons (Fig. $2 B$ and Fig. 7, $B$ and $E$ ).

In the fetal DA, vasa vasorum were restricted to the adventitia (Fig. 2D). After birth, vasa vasorum invaded the muscle media, even in the Control newborns (Fig. 2D). The baboons treated with Indo $+L-N A$ had a much greater ingrowth of vasa vasorum than those in the Control and Indo groups (Fig. $2 D$ and Fig. 7, $C$ and $F$ ).

The changes in VEGF and PCNA expression, as well as the changes in luminal and vasa vasorum endothelial cells, occurred only in the constricted portion of the Indo + L-NA DA, where there was extensive reduction in luminal size. In contrast, these changes were not detectable in regions from the same vessels where the lumen was still widely patent and EF5 binding was negligible (e.g. near the aortic end of the DA).

Systemic responses. L-NA caused a significant increase in systemic blood pressure that persisted for the duration of the infusion (Fig. 8). L-NA-treated animals required a transient increase in $\mathrm{FIO}_{2}$ (which was not statistically significant) during the first $12 \mathrm{~h}$ of infusion (Fig. 8). There were no differences between the two groups in other respiratory variables (Fig. 8), in arterial $\mathrm{pH}$ or base deficit, in hourly urine output (Fig. 8), or in other variables measured on d 6 (white cell, red cell, or platelet counts; total protein, albumin, globulin, creatinine, cholesterol, ALT, AST, alkaline phosphatase, gamma glutamyl transferase, lactic dehydrogenase, bilirubin, blood urea nitrogen, creatinine phosphokinase, or methemoglobin) (data not shown).

\section{DISCUSSION}

Our results demonstrate that prostaglandins are not the only important factor opposing DA constriction in the preterm newborn; NO plays an important role as well. The combined use of a NOS synthase inhibitor (either L-NA or MMA) and indomethacin produced a much greater degree of DA constriction in vivo than indomethacin alone (Figs. 1 and $2 A$ ). This is consistent with in vitro studies $(5,6)$.

Our results also demonstrate that, just like the full-term DA, the premature DA is capable of undergoing anatomic remodeling if it can develop the same degree of intense hypoxia that is observed at term. We found that the premature DA required tighter constriction, and more complete obliteration of its lumen, to produce the same degree of hypoxia observed at term (see Ref. 3). Despite the absence of Doppler-detectable luminal blood flow, a small, residual patent lumen was frequently present at necropsy in the premature baboons (Fig. 2A); even when the lumen appeared to be closed at necropsy, some degree of luminal perfusion (as measured by Hoechst bisbenzimide uptake) was frequently present (Fig. 4B). The most intense DA wall hypoxia occurred only when there was complete absence of luminal perfusion (Figs. 3 and $4 E$ ).

Hypoxia of the DA wall (or events that lead to the development of hypoxia) appears to be the required stimulus for anatomic remodeling. Although other explanations could account for the individual appearances of VEGF and cell death in the wall of the DA (26-32), their geographic distribution can be completely accounted for by the intensity and distribution of hypoxia, as measured by EF5 (Figs. 4, $E$ and $F, 5$, and 6). Moderate VEGF expression and cell death were observed only in the most constricted portion of the Indo $+L-N A$-treated DA (where EF5 binding was greatest); the changes were not detectable in sections from the same DA, where the lumen was 


\section{VEGF}
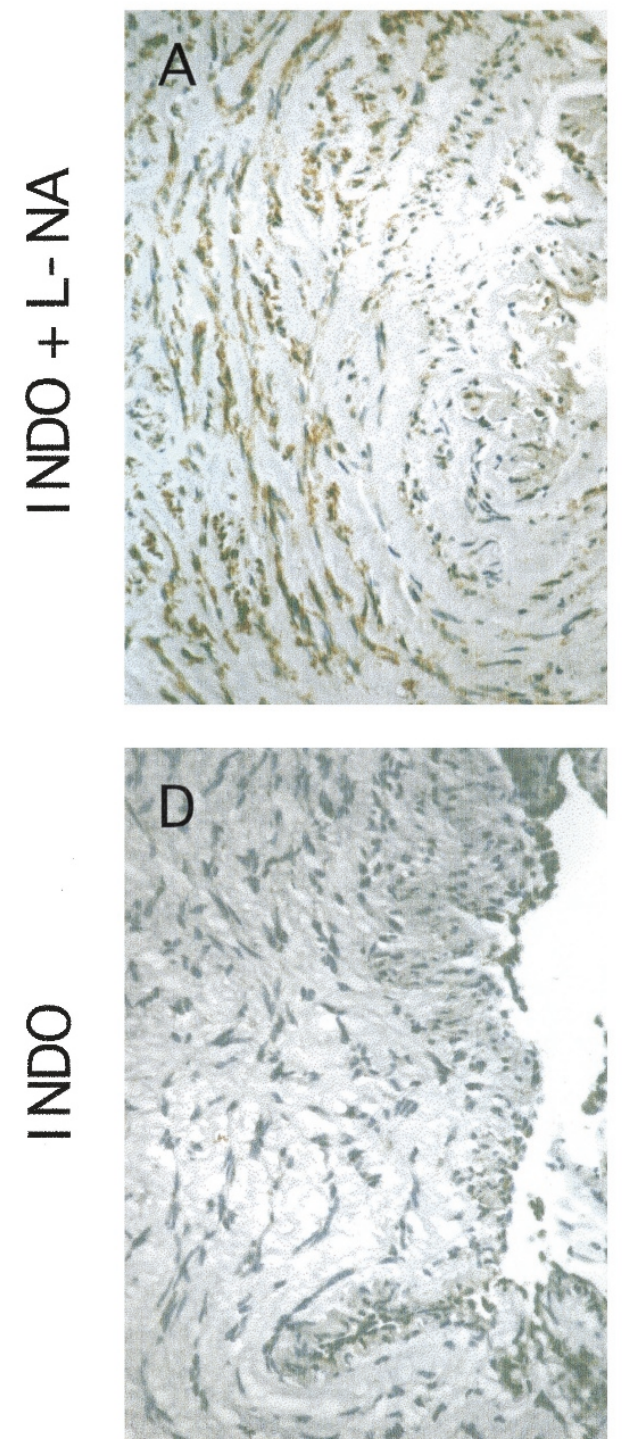

eNOS
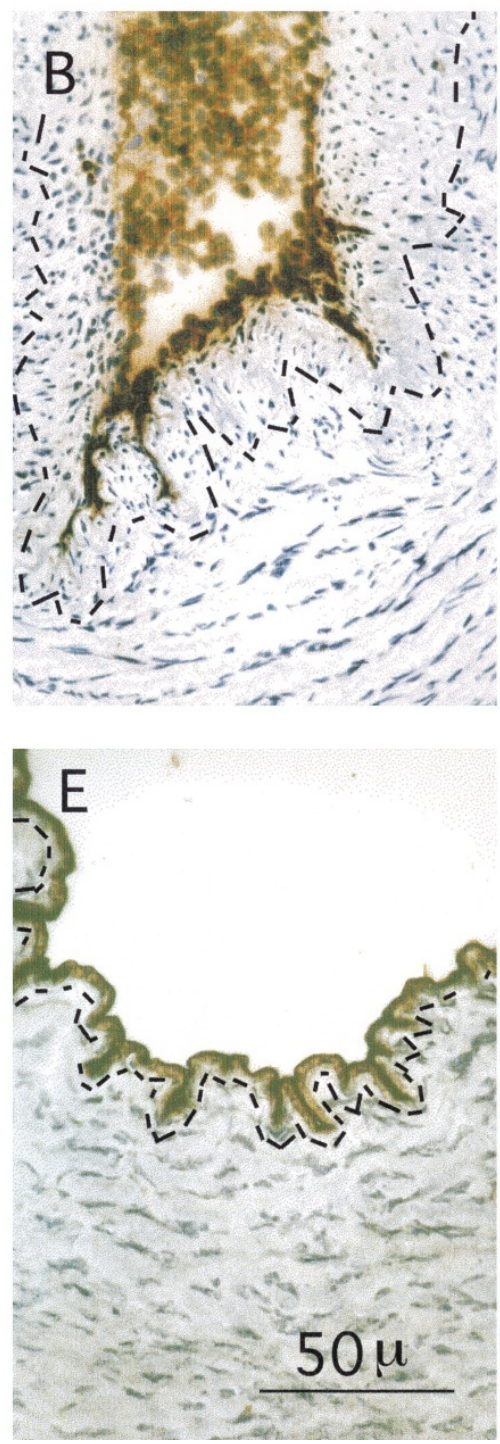

eNOS
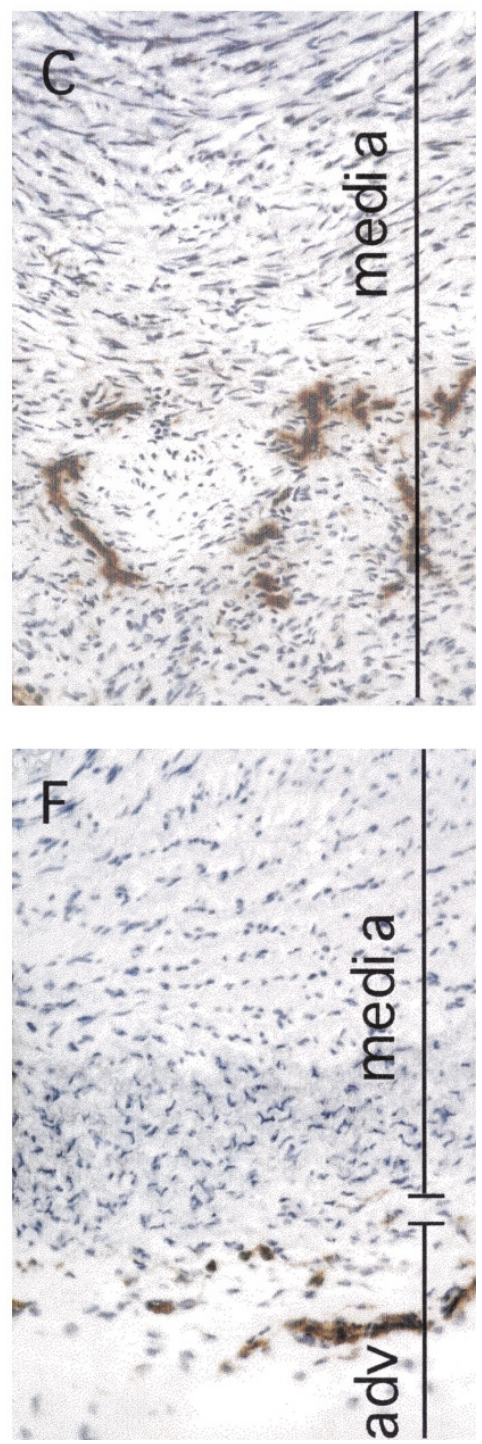

Figure 7. DA from preterm baboons treated with Indo $+L-N A(A-C)$ have increased VEGF expression, endothelial accumulation, neointima formation, and vasa vasorum ingrowth compared with baboons treated with Indo alone $(D-F)$. VEGF $(A, D)$ and eNOS $(B, C, E, F)$ positive immunoreactivity $=$ brown stain. Cell nuclei counter stained with hematoxylin (blue). Dashed black line $(B, E)=$ internal elastic lamina (identified by phase contrast microscopy). $(A)$ Moderate VEGF stain in Indo + L-NA DA vs no VEGF stain in Indo-alone DA $(D)$. (B) Widened neointima filled with luminal endothelial cells in Indo $+L-N A$ DA vs single layer of endothelial cells in Indo-treated DA $(E)$. (C) Vasa vasorum invade muscle media of Indo $+L-N A$ DA $v s$ less muscle-media ingrowth in Indo-treated DA $(F)$. Immunostaining for vWF or PECAM gave the identical pattern as for eNOS (data not shown). Horizontal bar represents $\mu \mathrm{m}$. Vertical brackets in $(C)$ and $(F)$ span the portion of the DA wall that is composed of muscle media (media) or adventitia $(a d v)$.

more widely patent and EF5 binding was negligible. Our current results are consistent with similar findings in different models of ductus remodeling (postnatal closure in the full-term newborn (3), indomethacin-induced constriction in the late gestation fetus (33), and hyperoxia-induced constriction in the preterm newborn (23)). It appears that, no matter what the stimulus is for ductus constriction, profound hypoxia in the ductus wall is required before remodeling can take place $(3,23$, 33).

Our studies support the concept that, even in the preterm infant, functional obliteration of the DA lumen is both necessary and sufficient to initiate the remodeling process. We hypothesize that the hypoxia-inducible growth factor VEGF may play a crucial role in neointimal expansion and vasa vasorum ingrowth because it stimulates endothelial cell proliferation and permeability $(34,35)$. Changes in luminal endothelial permeability also could increase the rate of neointima formation by increasing the access of medial smooth muscle cells to blood borne mitogens and chemoattractants (36).

Although evaluation of the systemic effects of NO inhibition was not a primary objective of our study, some preliminary observations are worth mentioning. Inhibition of NO production has been shown to increase vascular resistance and decrease carotid, renal, and mesenteric blood flows in adult humans and experimental animals (37-41). It also affects renal filtration and absorption (41-43), myocardial contractility 

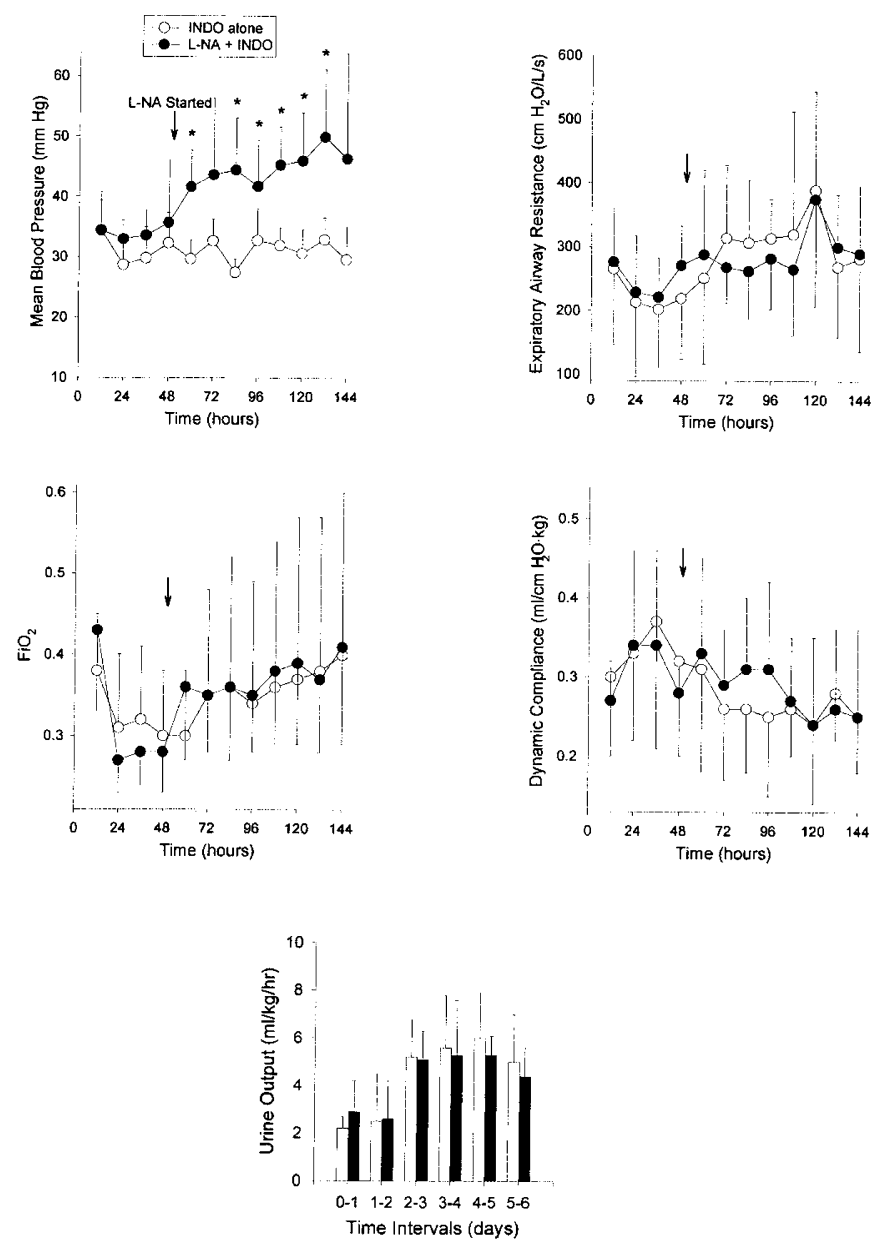

Figure 8. Relationships between DA treatment groups (Indo-alone vs Indo + $L-N A$ ) and measurements of mean systemic blood pressure, $\mathrm{FiO}_{2}$, expiratory airway resistance, dynamic compliance, and urine output. Values represent mean $\pm \mathrm{SD}$; significant differences between DA treatment groups are represented by asterisks $(p<0.05)$. Urine output is averaged over 24 -h intervals. Animals in both groups were treated with indomethacin starting at $24 \mathrm{~h}$ after delivery.

(44), and pulmonary vascular pressure $(39,40)$. Similar studies are not available in the extremely preterm newborn. We found that inhibition of endogenous NO production (in animals that were pretreated with indomethacin) caused a significant increase in systemic blood pressure. Our preliminary findings showed no significant evidence of systemic toxicity; however, future studies will be required to more thoroughly evaluate the possibility of local ischemic injury.

Our findings also address another important clinical observation: indomethacin is most effective in closing the preterm DA if it is given on the first day after birth; its effectiveness wanes with increasing postnatal age (11). After delivery, eNOS-expressing vasa vasorum invade the outer muscle media of the newborn DA. This occurs even in vessels without other evidence of anatomic remodeling (Fig. 2D, Control). These new vasa vasorum do not appear to express the enzymes that make prostaglandins (COX-1 or COX-2), (Clyman RI, unpublished results). During the first days after delivery, as more vasa vasorum grow into the newborn DA, it is possible that $\mathrm{NO}$ production may become as important as tissue prostaglandins in maintaining DA patency. As a result, indomethacin (which only inhibits prostaglandin production) would become less effective in producing DA closure. Drugs interfering with NO synthesis may become useful adjuncts in treating the patent DA, especially in situations where indomethacin has proven to be ineffective.

Acknowledgments. The authors thank Mr. Wesley Cox for his help in performing the Doppler studies, Dr. Brad Yoder for his expertise in managing the preterm baboons, Dr. Jackie Coalson for managing and coordinating the National Institutes of Health, NHLBI BPD Resource Center, Ms. Victoria Fontana and Ms. Daisy Fleming for editorial assistance, Ms. Vicki Winter and Ms. Linda Buchanan for organizing and distributing the tissues, and Ms. Janine Bekker for technical assistance. We also thank all the technicians in the NICU at the Southwest Foundation, San Antonio, TX, for their help in caring for the preterm baboons.

\section{REFERENCES}

1. Clyman RI, Goetzman BW, Chen YQ, Mauray F, Kramer RH, Pytela R, Schnapp LM 1996 Changes in endothelial cell and smooth muscle cell integrin expression during closure of the ductus arteriosus: an immunohistochemical comparison of the fetal, preterm newborn, and full-term newborn rhesus monkey ductus. Pediatr Res 40:198208

2. Tannenbaum JE, Waleh NS, Mauray F, Gold L, Perkett EA, Clyman RI 1996 Transforming growth factor- $\beta$ protein and messenger RNA expression is increased in the closing ductus arteriosus. Pediatr Res 39:427-434

3. Clyman RI, Chan CY, Mauray F, Chen YQ, Cox W, Seidner SR, Lord EM, Weiss H, Wale N, Evan SM, Koch CJ 1999 Permanent anatomic closure of the ductus arteriosus in newborn baboons: the roles of postnatal constriction, hypoxia, and gestation. Pediatr Res 45:19-29

4. Zemplenyi T, Crawford DW, Cole MA 1989 Adaptation to arterial wall hypoxia demonstrated in vivo with oxygen microcathodes. Atherosclerosis 76:173-179

5. Clyman RI, Waleh N, Black SM, Riemer RK, Mauray F, Chen YQ 1998 Regulation of ductus arteriosus patency by nitric oxide in fetal lambs. The role of gestation, oxygen tension and vasa vasorum. Pediatr Res 43:633-644

6. Coceani F, Kelsey L, Seidlitz E 1994 Occurrence of endothelium-derived relaxing factorónitric oxide in the lamb ductus arteriosus. Can J Physiol Pharmacol 72:82-88

7. Momma K, Toyono M 1999 The role of nitric oxide in dilating the fetal ductus arteriosus in rats. Pediatr Res 46:311-315

8. Fox JJ, Ziegler JW, Dunbar DI, Halbower AC, Kinsella JP, Abman SH 1996 Role of nitric oxide and cGMP system in regulation of ductus arteriosus tone in ovine fetus. Am J Physiol 271:H2638-H2645

9. Clyman RI, Mauray F, Roman C, Heymann MA, Payne B 1983 Effect of gestational age on ductus arteriosus response to circulating prostaglandin $E_{2}$. J Pediatr 102:907911

10. Clyman RI, Mauray F, Rudolph AM, Heymann MA 1980 Age-dependent sensitivity of the lamb ductus arteriosus to indomethacin and prostaglandins. J Pediatr 96:94-98

11. Narayanan M, Cooper B, Weiss H, Clyman RI 2000 Prophylactic indomethacin factors determining permanent ductus arteriosus closure. J Pediatr 136:330-337

12. McCurnin DC, Seidner SR, Edde EL, Cox WL, Correll DM, Coalson JJ 1995 Effects of early indomethacin on postsurfactant pulmonary hemorrhage in preterm baboons with respiratory distress syndrome. Pediatr Res 37:342A

13. Abman SH, Chatfield BA, Hall SL, McMurtry IF 1990 Role of endothelium-derived relaxing factor during transition of pulmonary circulation at birth. Am J Physiol 259:H1921-H1927

14. Gordon JB, Moreira GA, O'Donnell DC, Aldinger AM, Tod ML 1997 Relative effects of cyclooxygenase and nitric oxide synthase inhibition on vascular resistances in neonatal lamb lungs. Pediatr Res 42:738-743

15. Moore PK, al-Swayeh OA, Chong NW, Evans RA, Gibson A 1990 L-NG-nitro arginine (L-NOARG), a novel, L-arginine-reversible inhibitor of endotheliumdependent vasodilatation in vitro. Br J Pharmacol 99:408-412

16. Takahashi Y, Roman C, Chemtob S, Tse MM, Lin E, Heymann MA, Clyman RI 2000 Cyclooxygenase-2 inhibitors constrict the fetal lamb ductus arteriosus both in vitro and in vivo. Am J Physiol Regul Integr Comp Physiol 278: R1496-R1505

17. Kajino H, Chen YQ, Chemtob S, Waleh N, Koch CJ, Clyman RI 2000 Tissue hypoxia inhibits prostaglandin and nitric oxide production and prevents ductus arteriosus reopening. Am J Physiol 279:R278-R286

18. Koch CJ, Evans SM, Lord EM 1995 Oxygen dependence of cellular uptake of EF5 [2-(2-nitro-1H-imidazol-1-yl)-N-(2,2,3,3,3-pentafluoropropyl) acetamide]: analysis of drug adducts by fluorescent antibodies vs bound radioactivity. $\mathrm{Br} \mathrm{J}$ Cancer $72: 869-874$

19. Zeymer U, Fishbein MC, Forrester JS, Cercek B 1992 Proliferating cell nuclear antigen immunohistochemistry in rat aorta after balloon denudation. Comparison with thymidine and bromodeoxyuridine labeling. Am J Pathol 141:685-690 
20. Gordon D, Reidy MA, Benditt EP, Schwartz SM 1990 Cell proliferation in human coronary arteries. Proc Natl Acad Sci U S A 87:4600-4604

21. Collins RJ, Harmon BV, Gobe GC, Kerr JF 1992 Internucleosomal DNA cleavage should not be the sole criterion for identifying apoptosis. Int J Radiation Biol 61:451-453

22. Gavrieli Y, Sherman Y, Ben-Sasson SA 1992 Identification of programmed cell death in situ via specific labeling of nuclear DNA fragmentation. J Cell Biol 119:493-501

23. Kajino H, Chen YQ, Seidner SR, Waleh N, Mauray F, Roman C, Chemtob S, Koch CJ, Clyman RI 2001 Factors that increase the contractile tone of the ductus arteriosus also regulate its anatomic remodeling. Am J Physiology Regul Integr Comp Physiol 281:R291-301

24. Goldberg MA, Schneider TJ 1994 Similarities between the oxygen-sensing mechanisms regulating the expression of vascular endothelial growth factor and erythropoietin. J Biol Chem 269:4355-4359

25. Plate KH, Breier G, Millauer B, Ullrich A, Risau W 1993 Up-regulation of vascular endothelial growth factor and its cognate receptors in a rat glioma model of tumor angiogenesis. Cancer Res 53:5822-5827

26. Pertovaara L, Kaipainen A, Mustonen T, Orpana A, Ferrara N, Saksela O, Alitalo K 1994 Vascular endothelial growth factor is induced in response to transforming growth factor-beta in fibroblastic and epithelial cells. J Biol Chem 269:6271-6274

27. Cullinan-Bove K, Koos RD 1993 Vascular endothelial growth factor/vascular permeability factor expression in the rat uterus: rapid stimulation by estrogen correlates with estrogen-induced increases in uterine capillary permeability and growth. Endocrinology 133:829-837

28. Harada S, Nagy JA, Sullivan KA, Thomas KA, Endo N, Rodan GA, Rodan SB 1994 Induction of vascular endothelial growth factor expression by prostaglandin E2 and E1 in osteoblasts. J Clin Invest 93:2490-2496

29. Li J, Perrella MA, Tsai JC, Yet SF, Hsieh CM, Yoshizumi M, Patterson C, Endege WO, Zhou F, Lee ME 1995 Induction of vascular endothelial growth factor gene expression by interleukin-1 beta in rat aortic smooth muscle cells. J Biol Chem 270:308-312

30. Shweiki D, Neeman M, Itin A, Keshet E 1995 Induction of vascular endothelial growth factor expression by hypoxia and by glucose deficiency in multicell spheroids: implications for tumor angiogenesis. Proc Natl Acad Sci U S A 92:768-772

31. Liu Y, Christou H, Morita T, Laughner E, Semenza GL, Kourembanas S 1998 Carbon monoxide and nitric oxide suppress the hypoxic induction of vascular endothelial growth factor gene via the 5' enhancer. J Biol Chem 273:15257-15262

32. Finkenzeller G, Marme D, Weich HA, Hug H 1992 Platelet-derived growth factorinduced transcription of the vascular endothelial growth factor gene is mediated by protein kinase C. Cancer Res 52:4821-4823
33. Clyman RI, Chen YQ, Chemtob S, Mauray F, Kohl T, Varma DR, Roman C 2001 In utero remodeling of the fetal lamb ductus arteriosus: the role of antenatal indomethacin and avascular zone thickness on vasa vasorum proliferation, neointima formation, and cell death. Circulation 103:1806-1812

34. Leung DW, Cachianes G, Kuang WJ, Goeddel DV, Ferrara N 1989 Vascular endothelial growth factor is a secreted angiogenic mitogen. Science 246:1306-1309

35. Yuan F, Chea Y, Dellian M, Safabaknsh N, Ferrara N, Jain RK 1996 Time dependent vascular regression and permeability changes in established human tumor xenografts induced by an anti-vascular endothelial growth factor/vascular permeability factor antibody. Proc Nat Acad Sci U S A 93:14765-14770

36. Ross R, Glomsett JA 1976 The pathogenesis of atherosclerosis. N Engl J Med 295:369-377

37. Henderson JL, Statman R, Cunningham JN, Cheng W, Damiani P, Siconolfi A, Horovitz JH 1994 The effects of nitric oxide inhibition on regional hemodynamics during hyperdynamic endotoxemia. Arch Surg 129:1271-1274; discussion 1275

38. Schmetterer L, Findl O, Strenn K, Graselli U, Kastner J, Eichler HG, Wolzt M 1997 Role of $\mathrm{NO}$ in the $\mathrm{O}_{2}$ and $\mathrm{CO}_{2}$ responsiveness of cerebral and ocular circulation in humans. Am J Physiol 273:R2005-R2012

39. Stamler JS, Loh E, Roddy MA, Currie KE, Creager MA 1994 Nitric oxide regulates basal systemic and pulmonary vascular resistance in healthy humans. Circulation 89:2035-2040

40. Albert J, Schedin U, Lindqvist M, Melcher A, Hjemdahl P, Frostell C 1997 Blockade of endogenous nitric oxide production results in moderate hypertension, reducing sympathetic activity and shortening bleeding time in healthy volunteers. Acta Anaesthesiol Scand 41:1104-1113

41. Wolzt M, Schmetterer L, Ferber W, Artner E, Mensik C, Eichler HG, Krejcy K 1997 Effect of nitric oxide synthase inhibition on renal hemodynamics in humans: reversal by L-arginine. Am J Physiol 272:F178-F182

42. Haynes WG, Hand MF, Dockrell ME, Eadington DW, Lee MR, Hussein Z, Benjamin N, Webb DJ 1997 Physiological role of nitric oxide in regulation of renal function in humans. Am J Physiol 272:F364-F371

43. Bech JN, Nielsen CB, Pedersen EB 1996 Effects of systemic NO synthesis inhibition on RPF, GFR, UNa, and vasoactive hormones in healthy humans. Am J Physiol 270:F845-F851

44. Gauthier C, Leblais V, Kobzik L, Trochu JN, Khandoudi N, Bril A, Balligand JL, Le Marec H 1998 The negative inotropic effect of beta3-adrenoceptor stimulation is mediated by activation of a nitric oxide synthase pathway in human ventricle. J Clin Invest 102:1377-1384 